\title{
Undoing Gender: Contemporary Women Theatre Makers in India
}

\author{
Priyanka Sharma ${ }^{1}$
}

'Dr., Independent Researcher, New Delhi- India

\section{ORCID: P.S. 0000-0002-8248-0153}

Corresponding author / Sorumlu yazar: Priyanka Sharma,

Independent Researcher, New Delhi- India

E-mail/E-posta: sharrma.priyanka3@gmail.com

Submitted/Başvuru: 12.10.2021

Revision Requested/Revizyon Talebi:

30.10.2021

Last Revision Received/Son Revizyon:

30.10.2021

Accepted/Kabul: 30.11 .2021

\section{Citation/Atıf:}

Sharma, Priyanka. "Undoing Gender:

Contemporary Women Theatre Makers in India", Tiyatro Eleştirmenliği ve Dramaturji Bölümü Dergisi 33, (2021): 1-19.

https://doi.org/10.26650/jtcd.1008575

\section{ABSTRACT}

This paper draws a framework outlining performance methods and processes within women's theatre in twenty-first century India, along with a conceptualisation of its objectives and aesthetics, by focusing on the politics and production processes of three contemporary women theatre creators in India - Maya Krishna Rao, Mallika Taneja, and Savita Rani. It analyses the themes, theatrical languages, production techniques, styles, acting, and production and performance settings of the three woman theatre makers, contextualising the emergence and development of feminist theatre in India. It aims to understand how these performers and directors create and re/present women and their issues in relation to gender, culture, and society in India and beyond. Drawing from Elain Aston's analysis of feminist aesthetics in theatre, this paper seeks to unravel the feminist politics of structural changes that have taken place in the three contemporary women theatre makers.

Keywords: Contemporary Women's Theatre, Indian theatre, Feminist Theatre, Dramaturgy, Feminism 


\section{Introduction}

Feminist readings of classical literary texts by women playwrights, which gained momentum following Simone De Beauvoir's The Second Sex ${ }^{1}$ and Kate Millett' Sexual Politics, ${ }^{2}$ led to the creation of new women characters in dramatic literature and productions that were closer to real life women and their concerns and experiences, in contrast to conventional stereotypical masculinist literary and theatrical portrayals of women. Women [the majority of them identify themselves as Feminist] playwrights and theatre makers questioned the typical depiction of women in dramatic productions as the beloved, girlfriend, wife, mother, and vamp, with a presence based mainly on their familial and home-based relationships to heroes and other male characters in the productions. They reconstructed newer and varied autonomous theatrical re/presentations of women based on real life, everyday experiences and stories of women themselves.

Realising that a politics of patriarchy is embedded in theatre in India, women critics in India also analysed the construction and representation of women by men in theatre in India. Kinnari Vohra problematises male creations of women characters, which happens even in modern playwriting, asking women scholars, writers, and playwrights to create more and more real women characters in theatre. She emphasises the perpetual need for these women to be 'engaged in research with women in order to make better sense of women's life experiences', since in conventional and traditional plays, as she says, 'women characters are [only] used to enhance or depict complexities of the emotions of male characters'. ${ }^{4}$

It is, however, not simply that male dramatists have not positioned women in progressive ways. There are modern male playwrights, in India as well, who have created non-conventional women characters. But, for the most part, they have failed to represent the everyday lives of women, their struggles, and their empowerment. As Vohra elaborates,

They have not been able to create women characters that are truly independent, equal, capable, intelligent, and questioning. At best, [their] women characters are victims of patriarchal values perpetuated by family, caste and class. These women do not in any significant ways challenge the system and find a way out for themselves without being destroyed. ${ }^{5}$

\footnotetext{
Simon De Beauvoir, The Second Sex (New York: Blanche Knopf Publishers, 1953).

Kate Millett, Sexual Politics (US: Doubleday and co., 1970; US: University of Illinois Press, 2000).

Kinnari Vohra, "Women That Man Created", Theatre India: National School of Drama's Theatre Journal 3 (May 2001): 111.
}

4 Ibid., 114.

5 Ibid., 114. 
Women's theatre in India emerged resisting male centeredness in conventional theatre, ${ }^{6}$ following the identification and realisation of 'male-stream' ${ }^{\prime 7}$ in the field. ${ }^{8}$ Women's theatre in India is, thus, in its infancy, and is still in search of methods, techniques and theatrical language to eliminate mainstream conventional settings, aesthetics, and the male gaze in theatre, which if at its worst does not overtly harass women, then it does, at least make women the 'other', alienated and vulnerable within theatre. It started in the late twentieth century with the continuing effort of theatre makers such as Tripurari Sharma, Anuradha Kapur, Kirti Jain, Amal Allana, Sabitri Heisnam, Anamika Haksar, A. Mangai, Nilam Mansingh Chowdhry, Manjula Padmanabhan, Faezeh Jalali, Jyoti Dogra, etc. ${ }^{9}$ These women realised that the conventional method of play making and performance is in itself problematic and male-oriented, that the whole theatre tradition and aesthetics have been constructed by privileged men and through their worldviews. ${ }^{10}$ Their efforts in creating a women's stream in mainstream theatre and their discoveries of new methods regarding this kind of theatre-making have shaped practices in theatre that are not subjugating, suppressing, or harassing for women, both within theatre and among spectators, in public, and in society. These women theatre makers' realisation of the overarching presence and dominance of male-stream in mainstream theatre led them to create new theatre grammars that are evolving with their new theatre creations, along with their own languages, processes, and gaze that critically resist the conventional, dominant, oppressive, male-centric theatre mainstream. Elaine Aston ${ }^{11}$ has examined such processes and tools of women's theatre in the American context, which provides a broader framework for analysing women's theatre in the Indian context as well.

This paper will investigate theatre productions created by three such women theatre makers: Maya Rao, Mallika Taneja, and Savita Rani. It will examine how their theatrical themes, methods, techniques and tools create a theatre that serves the feminist purpose of undoing the dominant, patriarchally-constructed, binarised, stereotypical gender that is seen as natural, normal, and central in mainstream theatre and society. It will also examine how newer, changed, feminist, resistant aesthetics and gaze are constructed in the theatrical productions of the three theatre makers, and so in feminist theatre, and theatre generally, in India.

6 Nandi Bhatia, Performing Women/Performing Womanhood: Theatre, Politics, and Dissent in North India (England: Oxford University Press, 2010); also, A. Mangai, Acting up: Gender and Theatre in India, 1979 Onwards (New Delhi: Left World Publication, 2015).

7 The field/stream is created and dominated by men, for men, and is propagated/controlled by men. In Indian theatre, women had been excluded from writing, creating, performing and even witnessing it for centuries. Until recently, mainstream theatre was dominated by men; consequently, it was oppressive and it harassed and neglected women. Feminist critiques have renamed mainstream 'malestream' for this reason.

8 Anita Singh, “Aesthetics of Indian Feminist Theatre”, Rupkatha Journal on Interdisciplinary Studies of Humanities 1, no. 2 (2009): 150-170.

9 Anuradha Kapur, “A Wandering Word, An Unstable Subject”, Theatre India: National school of drama's Theatre Journal (May 2001): 5-12.

10 Ibid, 5-6.

11 Elaine Aston, Feminist Theatre Practice: A handbook (London: Routledge, 1999). 


\section{Realisation of Male-centric Conventions in Mainstream Theatre}

Women theatre makers are challenging and changing the symbolic order of theatre and theatrical language, which developed over a thousand years. ${ }^{12}$ Feminist theorisations have changed the conventional representation and image of women in theatre. Women's stories and experiences are now being told and represented with new, changed subjectivity and perceptions, with resistance and gender parity as the pillars of feminist theatre aesthetics. While mainstream theatre, continuing till now, represents women as objects, 'belonging' to men, women theatre making represents women as subjects in their own right, moving women's issues, stories, experiences, and perspectives to the centre stage. Women in contemporary theatre desire to be 'understood' or 'seen' not as a representation of masculinist imagination but as themselves, as women, fully. ${ }^{13}$ Feminist awareness and women's exploration is, thus, underway in contemporary theatre in India, re/activating an imagination in feminist theatre to resuscitate women and their images and bodies from the dominant, oppressive, suppressive, offensive, and stereotypical male aesthetics and gaze of mainstream theatre.

Contemporary women's theatre believes in the efficacy of theatre as a tool for 'conscientization', that is for critiquing gender and social disparities and for initiating an in depth process of self-exploration and self-expression. ${ }^{14}$ According to Laura Mulvey, while conventional and realistic visual and other narratives in theatre often produce plays that are a type of entertainment, with a certain sadism within it which demands a story, ${ }^{15}$ including women's stories, these hardly ever leave any room within them for depictions of women's agency. Feminist awareness in theatre, on the other hand, produces 'the rebel' theatre maker whose emphasis on women's agency demands a story, and sometimes not even stories, but ways and processes in which women's voices can be heard. For example, Maya Rao does not tell a conventional story, but reiterates a series of incidents of sexual violence against women and the impending conviction. ${ }^{16}$ This activates real, lived, and everyday re/presentation of the stories, experiences, and voices of women in performances, carrying forward this gendered sensitivity onto the spectators, simultaneously building an aesthetic of the oppressed and undoing dominant, binarised, stereotypical gender constructions, roles and identities.

The 'men's women' constructed in theatre and society as mainstream were and are different from how women themselves saw and see themselves. Recognising this problem of the

12 Anita Singh, "Aesthetics of Indian Feminist Theatre", Rupkatha Journal on Interdisciplinary Studies of Humanities 1, no. 2 (2009):164-166.

13 Aston, Feminist Theatre Practice: A handbook, 6.

14 Mohita Negi, "Rise of women's Theatre in India", Your Article Library; The Next Generation Library, accessed December 3, 2019, https://www.yourarticlelibrary.com/essay/rise-of-womens-theatre-in-india/24346.

15 Laura Mulvey, "Visual Pleasure and Narrative Cinema," Screen (1975): 8.

16 Maya Krishna Rao, "Walk", video, last modified, February 9, 2013, https://www.youtube.com/ watch?v=msUvCWKcCVQ 
male-stream within theatre, women theatre makers continuously undertook various theatrical experimentations and developed new methods of performance creation, with the intention of reaching out to and expressing women's own experiences and bodies, i.e. their bodily experiences. They intensified the writing of their own stories and narratives, magnifying the capacity of theatre to mark and re/present their desires and identifications. Women theatre makers, thus, strategically employed newer methods of theatre production to change mainstream representation of women, making them active social subjects, and not passive objects, in their theatres, ${ }^{17}$ destabilising conventional phallocentric aesthetics in theatre.

\section{Themes and Stories in Performances of Three Women Theatre Makers}

As Aston argues, feminist theatrical efforts lead women towards the creation of new theatres, ${ }^{18}$ where women can feel connected to the themes of their performances, expressing their own feelings and minds, addressing their own issues of suppression, and talking about their own desires and dreams. Here, theatre feels more real and natural, and is about, for, and by women. In this regard, women's theatre in India has explored a range of subjects, from domestic workers to sex workers, experiences from the home to the nation, from the business of sex to the business of arts, and more.

Women-based themes in theatre in India widely include various issues of women's rights, paving the way for the productions of the twenty-first century feminist and women theatre makers. By the 1990s, women theatre makers started centring themselves in their writings, developing and producing women's characters in theatre from their own life experiences. ${ }^{19}$ They portrayed women's struggles by exploring women to women relations, such as those of mothers and daughters, women friends, women workers, sex workers, women with different, non-heteronormative sexualities etc., in different languages. Maya Rao's Quality Streets (2017) ${ }^{20}$ for instance, re/presents a mother-daughter couple negotiating with the conventional meanings of marriage and culture, feudalism and democracy.

Women theatre makers brought in feminist subjects from across India, concentrating on women's issues, especially their struggles to be free of patriarchal oppression and inequality. Women playwrights and theatre makers, thus, began bringing new subjects and stories into theatre, portraying more 'authentic' women within it, focusing on 'their daily life, their sexuality

17 Teresa De Lauretis, Technologies of Gender: Essays on Theory, Film and Fiction (Indiana University Press, 1987): 109.

18 Dee Heddon, "The Politics of the Personal: Autobiography in Performance" in Feminist Futures? Theatre, Performance, and Theory, eds. Elaine Aston and Geraldine Harris (New York: Palgrave Macmillan, 2006): 139-140.

19 Nandi Bhatia, Performing Women/Performing Womanhood: Theatre, Politics, and Dissent in North India (England: Oxford University Press, 2010): xvi-xxiii.

20 Maya Krishna Rao, “Quality Streets,” video, accessed January 3, 2021, https://www.youtube.com/

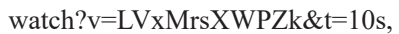


and desire, and their relationships with other women' ${ }^{21}$ In this context of women's theatre in India, this paper will examine in depth Maya Krishna Rao's Walk (2013), Mallika Taneja's Thoda Dhyan Se (Be Little Careful) 22 (2017), and Savita Rani's RIP 23 (2017).

In Walk, Maya dwells on the theme of a woman walking, going out, and being outside the home - the conventional, domestic, and confining sphere of activity for women - conceptually and practically, expanding the bounds of the woman self and feminising public spaces. Here, a woman's walk is an exploration of a woman being in dominantly patriarchal spaces - outside the home, on the streets, in the parks - while availing herself of her rights as not only a citizen of India but also as a full-fledged social human being.

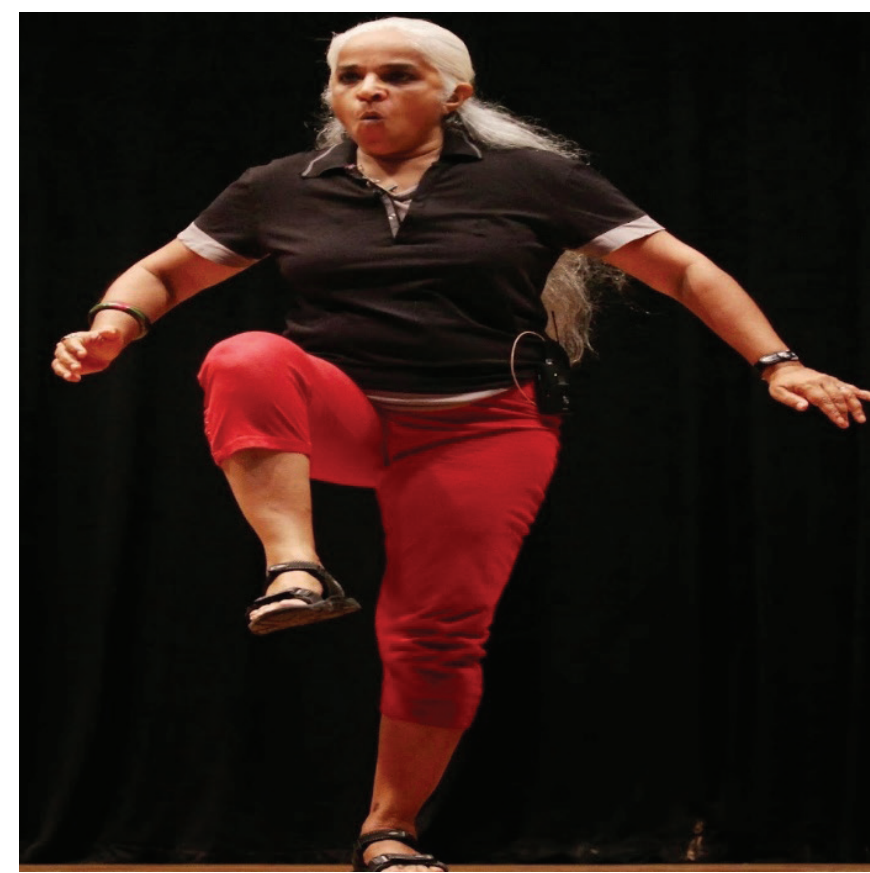

Maya Krishna Rao performing Walk, without a conventional story, character, or set, with only a factual, dissenting woman's voice asking for recognition and overcoming the everyday sexual violence in India that makes it possible for rapes to occur in the first place. Photo: mayakrishnarao.blogspot.com.

Walk is set in the context of the public discourse around sexual violence, which is conventionally centred on women's clothing place, timing, and her choices and freedom, but

21 Aishwarya Javalgekar, "How Feminist Theatre Emerged in India", Feminism in India, last modified August, 2017, https://feminisminindia.com/2017/08/30/feminist-theatre-india/

22 Mallika Taneja, “Thora Dhyan Se (Be Little Careful)," video, accessed February 2, 2021, https://www.youtube. com/watch?v=giNBlGGmxZg

23 Savita Rani, "RIP," video, accessed February 4, 2021, https://www.youtube.com/watch?v=LVxMrsXWPZk\&t=10s 
not on the criminal or the crime itself. While emphasising dismal rates of conviction for rape and sexual violence in India it sought to expand the discourse to include demands for equal rights, everyday freedom of movement, and gender justice for women, and more.

In Thoda Dhyan Se (Be Little Careful), Mallika dresses herself repeatedly, starting from wearing nothing and adding more and more clothing, till she is almost buried in clothes and accompanying paraphernalia. Each added layer symbolises conventional female decency as the appropriate clothing for women that is supposed to prevent sexual violence and rape.
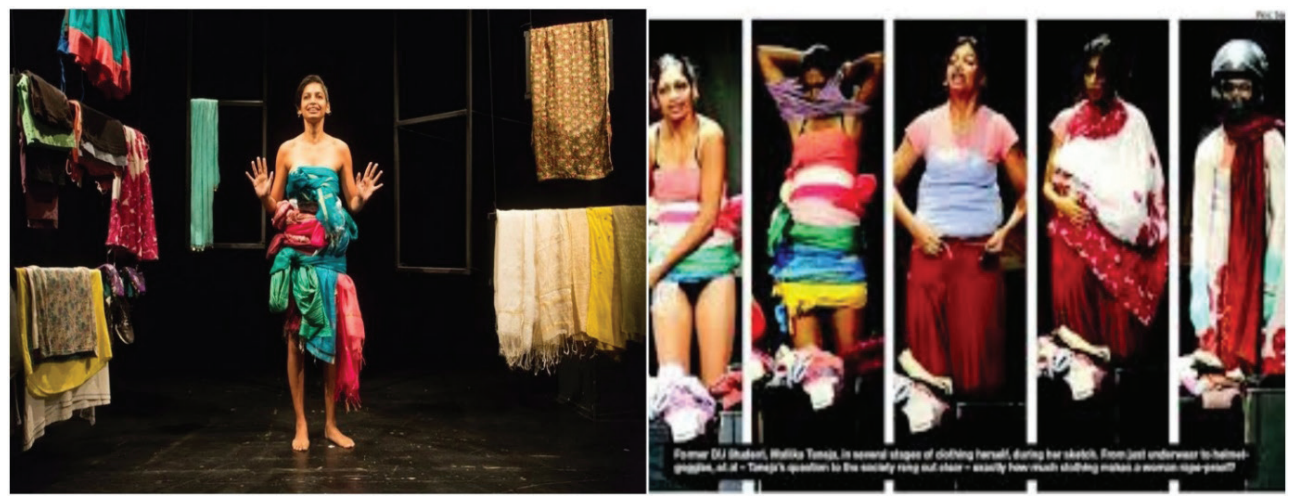

Mallika Taneja in Thoda Dhyan Se (Be Little Careful), questioning patriarchal notions about sexual harassment, especially victim blaming.

Photos: newsclick.com.

She repeatedly asks, with each added layer of clothing, if this new layer is guarantee enough for a woman to not be raped or sexually harassed. With this performance, Mallika opened up the debate on sexual violence while debunking the dominant myth that women's clothing, or the lack thereof leading to the exposure of women's bodies, is the cause of sexual violence, challenging patriarchal ideas regarding women's bodies and sexual violence against women in India.

In RIP, Savita, by subtly reimagining Sita of the Indian epic Ramayana as a modern woman with her own mind and desires, enquires into women's position in society and the gender performativity in Indian epics, theatre, and society that positions her as such, while at the same time re/presenting a journey of this woman finding her 'self', by herself. RIP explores the everyday politics of gender present in the institutions of family and marriage, reimagining why Sita, being a woman and the protagonist of the performance, actually leaves home in search of her own path. It is not merely to follow her husband as a devoted and obedient wife (even as she, Sita, initially and cleverly pretends that this is the case in order to get her way to fulfil her dream to travel when her options for this travel are otherwise limited) but to seek independence, freedom and growth for herself. 


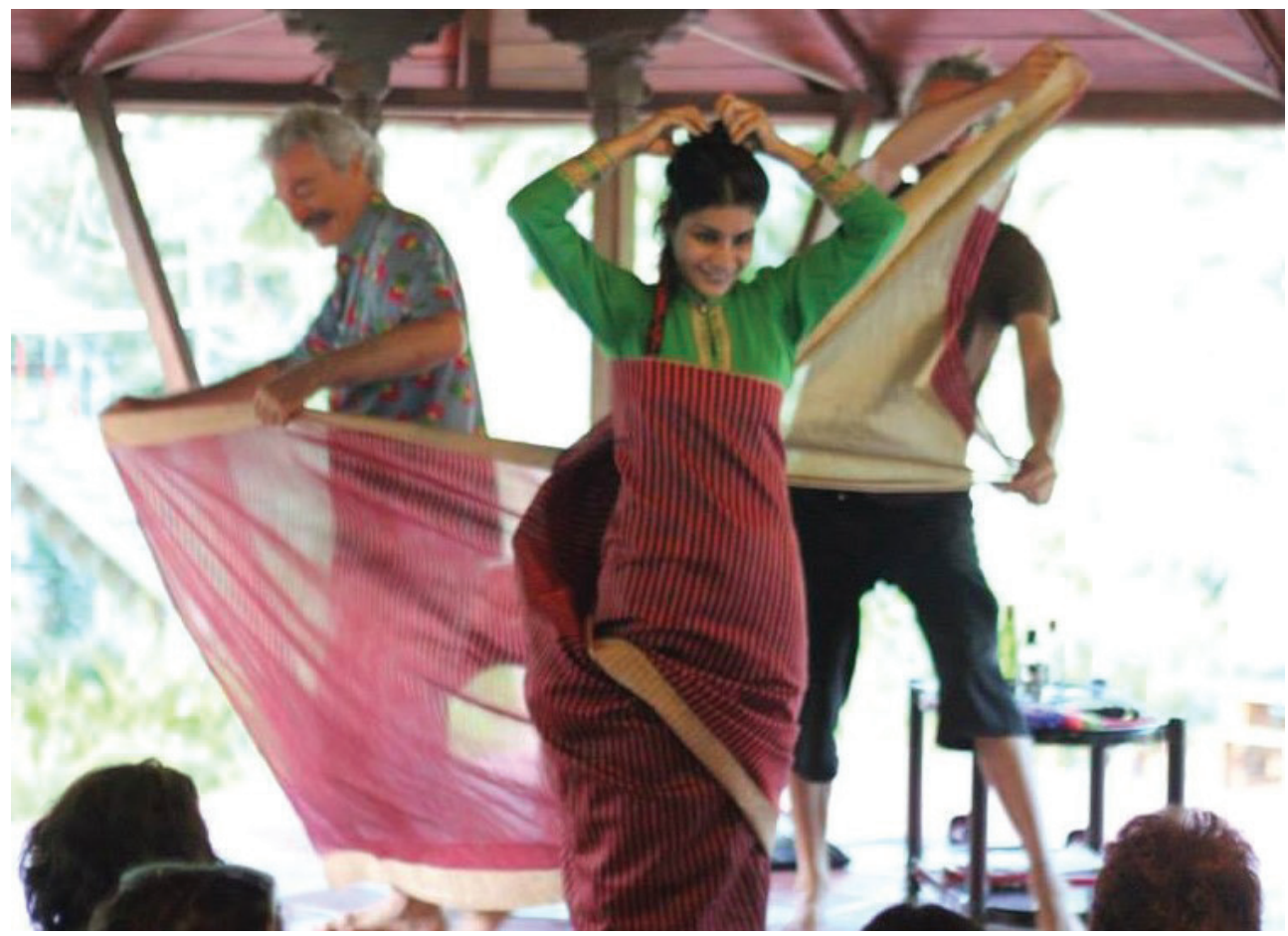

Spectators helping Savita put on a sari, symbolic of the relationship between women and culture. Photo: Savita Rani.

The women in the three performances do not re/present extraordinary women characters or heroic subjects or themes, but depict ordinary women speaking of their own experiences, in their own voices, against the everyday subjugation and violence that they come up against in all spaces and at all times. With this, the theatre makers create new textualities of/for feminist subjects in their performances, of women voicing their real experiences, opinions, views, and thoughts, which are largely ignored in conventional theatre. Further, as Mallika ${ }^{24}$ and Savita ${ }^{25}$ forthrightly say, the theatre makers create their performances not only because they want to express themselves but also because they want to connect with themselves, with the themes of their performances, and with the spectators, and induce active participation and conversation amongst all concerned, especially the spectators.

24 Mallika Taneja, interviewed by Kalki Koechlin, "My Indian life, Part-2: A Body of Protest" by bbcnews, video, accessed December 22, 2020, https://www.youtube.com/watch?v=9JT1BPBZO3A

25 Priya Srikumar, "Rest in Peace Throughout Life," Deccan Chronicle, 17 Feb, 2017,

https://www.deccanchronicle.com/entertainment/theatre/170217/rest-in-peace-throughout-life. html?fbclid=IwAR1newED6TCPQUyQbxjzFsbUdXTdG1ePxs4DmjHWAwaUVpP4qDGIc2_hMDY 


\section{Treating Spectators as Subjects}

Women's theatre has largely positioned spectators as not just passive viewing objects but as active, responsive subjects in theatre that speaks about, resists, and attempts to overcome gender and social discrimination. In an interview, Savita says,

While one feels that there must be a written text, lots of lights, set, music, make up and costumes in theatre...we must not forget that these are resources that also limit the possibility of theatre. The basic and foremost elements of theatre are the actor, the doer, the performer, and the spectator. ${ }^{26}$

It does not consider spectators to be mere targets of performances, indulging in voyeuristic and distant theatrical pleasure, but as subjects fully participating in the performances, filled with possibilities for social change and justice. It aims at the transformation of spectators into subjects, 'to enable or initiate positive changes in women's lives through political and theatrical representations'. ${ }^{27}$ As for Mallika, who chose a woman-centred performance because she wanted the spectators and the public to rethink their gendered notions and perspective and become gender sensitive, in her theatre spectators are subjects of change. ${ }^{28}$

These performances, thus, re/produce a gender and socially conscious spectatorship through new, changed, non-male-stream, non-mainstream theatrical textualities and expressions, and changed actor-spectator positions in theatre. With the new positioning of women's agency in theatre making, the actor-spectator relationship changes. Women's agency, brought forward in theatre through new stories, theatrical languages, and aesthetic creations of performances, becomes a new discourse for spectators. Conventionally silent spectators are taken by storm with this discourse, which stokes within them new perspectives and articulations of issues and experiences. This new positioning, made up of diverse women's agencies, is enabled by feminist theatre, which shifts the paradigm of a conventional, monopolist, male-centred, single narration of themes to include plural stories and perspectives of women placed differently and centrally in theatrical narration, with them telling their own stories on their own terms.

\section{Devising: Overcoming Male-centric Structures in Conventional Theatre}

Helene Keyssar, when examining feminist theatre in Britain and in the US, has articulated the overarching 'maleness' that is inherent within the traditional structure and making of

26 Priya Srikumar,"Rest in Peace Throughout Life", Deccan Chronicle, 17 Feb, 2017.

27 Negi, "Rise of women's Theatre in India," Your Article Library; The Next Generation Library, accessed December 3, 2019, https://www.yourarticlelibrary.com/essay/rise-of-womens-theatre-in-india/24346

28 Gaurangi Dang, Interview with Mallika Taneja, mumbaitheatreguide.com, accessed 9 February, 2021, https:// www.mumbaitheatreguide.com/dramas/interviews/mallika-taneja-interview.asp\# 
theatre. ${ }^{29}$ As feminist inquiries into dramatic literature conclude, conventional 'women's construction' within such literature is an attempt to make them secondary to men, who are always placed superior to women in these patriarchal discourses. Women's characters are represented as oppressed and subjugated, without any significant consideration for their varied real-life experiences or for their diverse thoughts, opinions and perceptions. Conventional, dominant, and scripted plays largely follow this same discourse and pattern of re/presentation of women, and men.

On the other hand, as Alison Oddey observes, devising, which is a non-scripted theatre production method, opens up the possibilities of changing this gendered conventional representation and positioning of women ${ }^{30}$ and men within theatre. Women theatre makers in twenty-first century India, who have each arrived at this consciousness differently, have not only rejected conventional, well-written plays but have also evolved new techniques of theatrical productions by embracing the free-flowing method of devising as the core of their theatrical processes. As Aston articulated, these 'feminist playwrights and practitioners who felt alienated by the realist structures of "women-belonging-to-men" [in conventional theatre] wanted to explore other theatrical forms and acting styles to represent their experiences, themes or subjects'. ${ }^{31}$ Considering the conventional relationship of women with culture, their un-real representation in male-stream, mainstream theatre, and the possibilities for political resistance opened up with devising in theatre, feminist theatre practitioners globally have used devising in/for their theatrical productions. Thus, although 'devising is not in itself a political practice... [it] does offer political possibilities'. As Aston, while highlighting the possibilities offered by devising for women theatre makers, says, this at least 'means that [the theatre makers] do not have to work on a "big daddy script" or, if constrained to do so, may assist in making a radical intervention in a "canonical" or "conventional play text". 32

In India, devising as a method of theatre creation has enabled contemporary feminists and women theatre practitioners such as Maya, Mallika, and Savita and others to contest and destabilise conventional dramatic texts, offering a variety of ways to address and expand upon theatrical content and form for voicing a plurality of experiences ${ }^{33}$ on themes of gender, women's repression, subjugation, and marginalization, in contrast to otherwise conventional single masculine narratives about women or gender in theatre and in society as well.

Maya, a pioneer in India in adapting devising techniques in theatre, has rejected and not used well-written dramatic texts for any of her performances in the last two decades, regardless

29 Helene Keyssar, Feminist Theatre: An Introduction to Plays of Contemporary British and American Women (Macmillan Education, USA, 1985): 1-20.

30 Alison Oddey, Devising Theatre; A Practical and Theoretical Handbook (New York: Routledge, 1994): 1-7.

31 Aston, Feminist Theatre Practice; A Handbook, 7.

32 Ibid, 15.

33 Oddey, Devising Theatre; A Practical and Theoretical Handbook, 6-7. 
of their genre, feminist or otherwise. For instance, Maya's Deeper Fried Jam ${ }^{34}$ (2013) is a 'socio-political cabaret show' performed in Brechtian style where she transformed herself into characters ranging from a labourer's child to that of the narrator to being a commentator on the misery caused by social and political disparity in society. Her need for narrating the emotions of the child with a political awareness fragmented her performance, turning her into a child, a performer, an artist, and a woman activist, one after the other, throughout the duration of her performance. Her breaking into various characters and emotions also compelled spectators to become aware of and interrogate their own thoughts and feelings regarding the societal conditions underlying the performance. The sudden appearance of images of construction workers, the direct depiction of a labourer's child, Maya's becoming various characters all interspersed with one another, the minimal use of sets and props - there is no set to indicate a construction site in the performance - all resulted from Maya's theatrical explorations for the performance through devising. Devising, she joined together various feelings, descriptions, narrations and commentaries from a variety of perspectives, including those of a performer and a common civic woman. With the resulting performance, spectators are always aware that Maya is not only a dramatic character in theatre but a re/presenter responsibly responding to realities, situations, and events surrounding her and them, attempting to lay a path of personal, societal, and theatrical change for all concerned.

With Walk, Maya offers a self-conscious narration of everyday gender brutalities across India. She uses techniques of agitation and explication in the performance, utilising only her voice to express agony, anger, and dissent, with the intent of sensitizing spectators regarding sexual violence against women in India. Her performance turns into activism, a perfect instance of a woman theatre maker exploring her 'self' in her performance, explicitly making clear that she too is a victim and survivor of violence and part of the protest against it. With such theatrical productions and interventions, feminist theatre decentralises conventional plays from their traditional settings and patriarchal aesthetics and representations, turning the bodies of women from conventionally being mere objects of masculine desire, pleasure, or sympathy into vocal and located bodies of activism. In Walk Maya does not take up a story or character as her content for her performance but works with facts about instances of rape and rape convictions in India, and closely associated everyday instances of seen and unseen gendered violence experienced by women that underlie and facilitate the rapes in the first place. With this, she exercises her civil rights as a dissenting woman, joining her voice with those of thousands of others regarding a current societal issue through theatre.

In RIP, Savita explores the relationship of women with culture. As a feminist performer, she feels the need to use her lived experiences and prevalent narratives about women and culture

34 Maya Krishna Rao, "Deeper Fried Jam,” accessed December 21, 2020, https://www.youtube.com/ watch?v=Uv7UdXvrybU 
and present these juxtaposed and contested to spectators to not merely induce emotions among them, but to activate reflective thoughts and actions in them, something which conventional theatre fails to do. In revisiting cultural history from a modern woman's perspective, RIP required and introduced new theatrical techniques and styles for constructing and re/presenting non-conventional, lived, and progressive cultural meanings of femininity, intelligence, violence, rape, and freedom about women in India.

Savita envisions theatre in a Brechtian sense, as an interactive engagement between performer and spectators, and becomes compelled to devise her performance, resulting in the use of photographs, a map, commentary, emotions, and the transformation of her character from that of a performer to a commentator and reviewer, among other things, in her performance. Effectively, she makes the spectators participate in her narration and performance - for instance by making them take on performative parts in the performance, like wrapping a sari around her and helping her with her hair, etc., all while she narrates and questions the importance attributed to rigid conventional cultural beliefs and norms regarding women in India with humour and with the spectators' active physical and reflective involvement.

In RIP Savita performs a mythical story using narratives of the past and present, of myth and reality. Savita, being as a modern woman performer, travels through the ages as Sita or any other mythical woman, inspecting concepts of gender and its performance in our cultural lives, which still shape the lives of contemporary girls/women. Savita creates a new feminist reading of a patriarchal myth in her performance by filling Sita's silence with words, providing reasons and revealing the motivations of other characters, and by critical analysis of Ramayana's story using her own experiences, consciousness, and perspective on gender and violence against women. Devising gives Savita a way to be herself and yet a character, to be a commentator and yet a woman with lived experiences of gender, sexuality, class and caste, re/presenting all this as a performer in her performance.

Maya and Savita both choose devising as the method for the development of their performance because of the possibility that devising offers them for being themselves, that is being the women that they are and still being 'performers' simultaneously, without giving up but rather building upon their own consciousness, intelligence, and feelings in their performances, something that conventional scripted plays deny them. With this choice, they consciously and otherwise intensively problematise women's marginalisation and exclusion from conventional playwriting and role distribution in theatre, which objectifies and straightjackets women's roles and images in theatre and limits the range of emotive possibilities available to them as performers.

Realising the authoritarian, 'male-stream' nature of dramatic texts, Maya and Savita, among other women performers in India, have used devising techniques to make their own 
theatre performances, challenging the conventional authoritative theatrical textual tradition and production process. Mohita Negi articulates,

It has meant departing from the conventional way of producing and staging plays. It has also meant addressing modes of performances, idioms of expression and representation of women, and using training in theatre for articulating the perception and aspiration of women. From creation of the script through improvisation and visualization on to rehearsal, right up to performance and relating to the audience, the emphasis has been on collective function. ${ }^{35}$

Rejection of written scripts is a political act of feminist consciousness in modern theatre in India. As Aston and Harries have observed for American feminist theatre, for Indian feminist [women-led] theatre as well, this meant that 'symbolic framings of women as Woman were contested as feminist theatre practitioners refused to be objectified, gazed upon, refused to be the "Other" in some (male) body else's story'. ${ }^{36}$ As Aston says, 'creating texts through the agency and creativity of the performer is what characterizes devising work, ${ }^{37}$ and this facilitates an agential embodiment of egalitarian consciousness in theatre, in India, and globally.

\section{Rejection of Realistic Acting}

It is well known that presentational, or realistic, acting leaves no creative space for the actor involved. The actor is merely presenting what is written in a script by a playwright or what $\mathrm{s} /$ he is told to present by a [male] director, within this conventional mode of acting. Rejecting this form of acting has, thus, been popular preference in women's theatre for two major reasons: one, for creating 'feminist subjects' in acting or in performance; and second, for critically reconstructing the dominant aesthetics of the oppressive representation of women created by the male-stream in theatre.

Realistic acting demanded by stereotypical characterisations limits the experiences and stories of women that can be performatively shared, because of the very presentation and process involved in it. As Ellen Sue Case has argued, 'the psychological construction of character, using techniques adapted from Stanislavski, placed the female actor within the range of systems that have oppressed her very representation on stage'. ${ }^{38}$ Besides representation, the principles and process of presentational acting are in themselves oppressive for women actors, when within these explorations of her "self" she is blocked and her voice is silenced. In conventional theatre, production scripts are linear and women's roles are created in relation to the those of the men in the scripts, so that women exist in these productions as supplemental attachments to

35 Negi, "Rise of women's Theatre in India," Your Article Library; The Next Generation Library, accessed December 3, 2019, https://www.yourarticlelibrary.com/essay/rise-of-womens-theatre-in-india/24346

36 Elaine Aston and Geraldine Harries, "Introduction" in Feminist Futures? Theatre, Performance, and Theory," eds. Elaine Aston and Geraldine Harries (New York: Palgrave Macmillan, 2006): 5.

37 Aston, Feminist Theatre Practice: A handbook, 143.

38 Sue-Ellen Case, Feminism and Theatre (London: Routledge, 1988): 122. 
men, and not independently as a unit of society and the world. Women characters, with limited emotions and feelings, do not offer much theatrical scope and range to women performers. Further, as Aston says, "the character roles made available for women to "get into" in this "method" invite the actress to identify with the oppression of the female character to which she has been assigned'. ${ }^{39}$ Consequently, Women theatre makers do not find realistic acting fulfilling their concerns, neither for an enactment of issues concerning them nor for creating dialogic actor-spectator relations with an intent to induce a real change in conventional theatre, its aesthetics, and in women's position in theatre and society.

As such, realist acting remains an obstacle to be rooted out for contemporary women's theatre in India, ${ }^{40}$ as elsewhere. Maya, Mallika, and Savita, among others, have rejected realistic acting that promotes scripted and stereotyped characters, especially women characters, in performances, bound by limited emotions and contexts for the entirety of a play. They make use of estrangement effects ${ }^{41}$ in their performances, as a fundamental way to rescue their performances from dominant realistic theatre, which largely involves merely presenting a character, a situation or a feeling in and as performance. For instance: in her each of her performances, Maya uses narratives to represent different characters, commentary to create humour and dialogue, and storytelling and mimicry to present emotions of women as women, within the same performance; Maya and Mallika use theatre exercises and varied sound effects to create alienation between performer and spectator, to reveal complex inner feelings of women regarding specific situations; and Mallika and Savita use commentary, dialogues and direct questions posed to the audience (for example, is it the clothing of a woman that causes sexual violence or the violator himself?). All three theatre makers embody a feminist need for changing common, dominant, and patriarchal perspectives surrounding gender violence and victim blaming, and other similar discourses and practices, which cannot be addressed by telling one woman's story, but by presenting many women-centred situations and perspectives regarding a situation or an issue in a performance directly to the audience and seeking their reflective 'self-experiences' on the matter.

The need for putting spectators in the position of activist is a larger feminist objective and method acting as such does not offer much to feminist and women theatre makers in this regard, leading them to experiment in theatre, with techniques such as inclusion of Brechtian principles of acting, folk songs, storytelling, impersonation, and fragmented presentation, in order to non-conventionally reframe gender in their performances. As a result,

39 Aston, Feminist Theatre Practice: A handbook, 7.

40 Anita Singh, “Aesthetics of Indian Feminist Theatre", Rupkatha Journal on Interdisciplinary Studies of Humanities 1, no. 2 (2009): 11.

41 It comprises of different techniques of multimedia/posters/break-in-acting/ a third person narration that breaks the emotional involvement of the spectator from the performance, and remind them of artificiality of the characters, and aims to activate conscious and critical thinking on the issue being present on the stage. 
Feminist plays do not always follow a linear narrative of exposition-conflict-resolution. They are focused on the recognition of bias or injustice, and often lead to open-ended conclusions. As such, feminist narratives are more fluid, juxtaposed between past and present or between the lived experiences of more than one protagonist. ${ }^{42}$

Not only do women theatre makers reject realistic acting, they also use non-realistic and non-conventional costumes, make-up, and sets in their performances in order to undo gender and construct a women-centric theatrical aesthetic, not to realistically match with the characters or situations in the performance but to enhance the performance and its theme metaphorically and symbolically. This often entails the performers dressing and undressing themselves in the course of their performances. For instance, Maya dons absurd costumes, as per the theme of her performance. Mallika starts her performance nude and then adds layers upon layers of clothing, till her costume becomes more and more absurd, overtly pointing at the societal hypocrisy of victim blaming, which would highlight her not being decently dressed and behaved, in most instances, as the cause of the sexual violence inflicted upon her. Savita wears an elegant feminine dress to start with but then takes it off during her performance, indicating freedom from the suffocation that women suffer when compulsorily partaking in patriarchal societal dressing and behavioural norms. Similarly, women theatre makers do not use conventional, elaborate, or spectacular stages and props in their performance spaces, but explore their and their performance themes' relationships with often non-conventional rehearsal and performance spaces, with their bodies, and through their and spectators' everyday experiences, mostly making use of fabric and ordinary lights as/for props, lighting and sets.

\section{Changing Conventional Image and Discourse about Women's Bodies}

Women's bodies, when exposed in theatre, in the opposite order of the male gaze, become a site of protest, breaking not only the gaze, which is necessarily male in conventional patriarchal society and theatre, but also creating a feminist spectacle through such expositions, with its theatrical languages, gestures, actions, set and light designs, make up and costumes. Feminist theatre makers turn themselves into 'spectacles' with the objective of showing how women are objectified in dominant, patriarchal, social, and cultural systems of representation, as in conventional theatre. Savita does this in RIP when she, humorously, takes the audience through elements of conventional acting and performance, ridiculing how a woman should sit, walk, laugh, talk, and sleep on the performance stage and in society. As such, women performers break theatrical conventions regarding the body, and women's bodies at that, in order to register their physical, logical, and political resistance to patriarchy, creating new presentations and meanings of gender, equality, and reality. ${ }^{43}$

42 Javalgekar, "How Feminist Theatre Emerged in India".

43 Anita Singh, "Aesthetics of Indian Feminist Theatre", Rupkatha Journal on Interdisciplinary Studies of Humanities 1, no. 2 (2009): 9-10. 
In Thoda Dhyan Se, Mallika goes naked to present to spectators and the public that sexual violence against women has nothing to do with her clothing, using her own gendered and sexualised body as a tool for fighting back against a patriarchal culture that blames the victims and survivors of sexual harassment and rape (women) for sexual violence against them, and not the men or the patriarchal system that perpetuates it, not in the least by managing and subjugating women's bodies and desires. With this act, Mallika becomes an integral part of changing conventional notions regarding women's bodies in public, highlighting and creating a different meaning for a naked female body in public, as a battle site for gender equality. ${ }^{44}$ In the performance, her (a woman's) naked body refuses to titillate, to evoke lust or desire, or to assume any sexualised forms that while being considered immoral in public are implicitly more acceptable in/to society than this other, newer, portrayal of women's bodies as horrifying, powerful, and completely and autonomously naked. ${ }^{45}$

Acts of women performers, such as Mallika's, break theatrical conventions while simultaneously reclaiming themselves and women's bodies from conventional and restrictive socio-symbolic values of patriarchal order. Resistance against violence, objectification, and sexualisation on stage builds a new landscape of women's bodies and constructs a womencentric gaze in theatre and society. The aesthetics of feminist theatre in India bring together theatre of resistance, with its focus on social justice, and feminist theory and activism, with its focus on gender inequality, body politics, and explorations of women-self, using women's own bodies as sites of critique and liberation.

Maya, in Walk and Comedies, performs wearing non-conventional costumes, exposing and covering her body in ways considered neither sexy nor cultured. Donning kajal to highlight her eyes, which are covered in partly glittery make up, and enacting non-feminine physical gestures, she presents an 'unwomanly woman' in public and in her performance, while at the same time, in the same performance, mimicking a very feminine woman, she theatrically expresses the binarised dualities, ironies, and burdens that a woman faces in the dominant patriarchal system. Savita in RIP, in another vein, performs and expresses the artificial and external efforts a woman makes to be womanly and to please her husband and society, contrary to who she really is and what she desires to be and do. She mimics and exaggerates these efforts and associated gestures that women undertake in society and theatre, along with a commentary on how she and other everyday women are not automatically and naturally womanly, as is conventionally believed, and how it is the mainly invisible but all pervasive societal pressure and expectation, that makes a woman become a 'womanly woman', exposing the falseness and violence of gender performativity and dominant gender norms in society

44 Claudia Pajewski, “The Indian Woman Using her Body to Fight for Equality,” bbcnews.com, accessed December 3, 2019, https://www.bbc.com/news/world-asia-india-42349844

45 Trina Nileena, Banerje, "Written on the Bodies," Agenda 4, (January 2006): 20-23. 
and theatre. Maya, Mallika, and Savita all question the conventional image of women in the public sphere and creatively reconstruct this image as they include their own perspectives, simultaneously overturning dominant norms of conventional dramaturgy and the centrality of the male protagonist in conventional theatre and society.

\section{Conclusion}

Contemporary women's theatre and the themes, agency, and gaze offered by it are creating new paradigms of spectatorship. It has changed the meanings and aesthetics of women's images re/presented in performances, transforming conventional vulnerable and sexual images of women into multiple egalitarian images of vocal, resistant, and free women.

In India, many women theatre makers have made gender, femininity, and sexuality and its varied lived experiences the theme of performance. For them, women are not conventional passive objects or the masculine creations of male theatre makers, but active subjects undoing gender and rejecting phallocentrism in theatre and society. Their theatrical productions about women and gender are creating new grammars in theatre through their explication of gender performativity in their performances. Their performances reiterate gender ironies, undoing gender by exposing the non-naturalness and constructed-ness of gender, which is fabricated by patriarchy.

Maya Krishna Rao's Walk, Savita Rani's RIP, and Mallika Taneja's Thoda Dhyan Se (Be Little Careful) are contemporary theatrical works undoing gender by consciously recounting and mimicking gender constructions and exposing its inherent, ironic inconsistencies in their performances. The three women theatre makers reject realistic acting for their performances, relying more on the use of narration and commentary instead, which helps them transform from being characters to being women in their performances, expanding their space for the theatrical sharing of themes and experiences that relate to them, and connecting with other women and the world. They recount their stories in their performances with their subjective experiences and thoughts, becoming a voice of feminist politics that speaks for women, a suppressed gender in theatre and society.

As can be seen, women's theatre in India inherently challenges the codes of gender construction and inequality, sexuality, and body politics embedded in conventional patriarchal social setups in India. Women theatre makers in India aim to encourage spectators to see differently from that of the male gaze that is conventionally presented to them by theatre. Their dialogic performances allow spectators to actively participate in the performances while generating newer and changed meanings of gender within socio-symbolic patriarchal orders. Newness and a variety of women-centric narratives in the performances provide spectators, theatre, and society with diverse critical perspectives on concerning issues. 
Devising remains at the core of fostering newer and feminist styles of theatrical presentations, free of the encumbrances of conventional stagecraft, make up and costumes, making the performances free flowing, located in lived experiences, affordable, and accessible. This also enables and encourages many more women to be theatre makers, exploring their 'self', their experiences, and bodies and associated identity politics, resisting sexual and gender violence, and undoing gender by various means in public. As such, feminist models of non-realistic acting and presentation, have, in turn, canonised themselves, with their theatrical methods of creating dialogues, making discourses, and feminising public spaces compelling spectators to be critical and political, and ultimately strive for equality regarding gender and everything else.

The implication of the theory and practice of new spectatorship in women's theatre is that it makes it possible to change the conventional male gaze in theatre and society into a new, alternate, and progressive gaze of a different spectatorship. Using new themes and stories directly and indirectly from the lived experience of theatre makers and spectators regarding patriarchy and its operation, violence, struggles, and experiments, and by undoing gender, feminist and women theatre makers are part of changing the idea of woman, gender and culture. Still, more can be, and has to be, done. As Aston says, women and feminist theatre makers and spectators, that is the entire society, has "more to gain through "undoing" the social, cultural and theatrical conditioning of their bodies'. ${ }^{46}$

Peer-review: Externally peer-reviewed.

Conflict of Interest: The author has no conflict of interest to declare.

Grant Support: The author declared that this study has received no financial support.

Hakem Değerlendirmesi: Dış bağımsız.

Çıkar Çatışması: Yazar çıkar çatışması bildirmemiştir.

Finansal Destek: Yazar bu çalışma için finansal destek almadığını beyan etmiştir.

\section{BIBLIOGRAPHY / KAYNAKÇA}

Aston, Elaine. Feminist Theatre Practice: A Handbook. London: Routledge, 1999.

Banerjee, Trina Nileena. "Written on the Bodies", Agenda, issue 4, (January 2006), InfoChange News and Feature, Centre for communication and development studies.

Bhatia, Nandi. Performing Women/Performing Womanhood: Theatre, Politics, and Dissent in North India. England: Oxford University Press, 2010.

Case, Sue- Ellen. Feminism and Theatre. London: Routledge, 1988.

De Beauvoir, Simon. The Second Sex. Yew York: Blanche Knopf Publishers, 1953.

De Lauretis, Teresa. Technologies of Gender: Essays on Theory, Film and Fiction. Indiana University Press, 1987.

46 Aston, Feminist Theatre Practice: A Handbook, 15. 
Gaurangi Dang, Interview with Mallika Taneja, mumbaitheatreguide.com, accessed October 30, 2019, https:// www.mumbaitheatreguide.com/dramas/interviews/mallika-taneja-interview.asp\#

Heddon, Dee. "The Politics of the Personal: Autobiography in Performance" in Feminist Futures? Theatre, Performance, and Theory, edited by Elaine Aston and Geraldine Harries. New York: Palgrave Macmillan, 2006.

Javalgekar, Aishwarya. 'How Feminist Theatre Emerged in India', Feminism in India, last modified August, 2017, https://feminisminindia.com/2017/08/30/feminist-theatre-india/

Kapur, Anuradha. "A Wandering Word, An Unstable Subject”, Theatre India: National school of drama's Theatre Journal. no. 3 (May 2001).

Keyssar, Helene. Feminist Theatre: An Introduction to Plays of Contemporary British and American Women. USA: Macmillan Education, 1985.

Mangai, A. Acting up: Gender and Theatre in India, 1979 Onwards. New Delhi: Left World Publication, 2015.

Millett Kate, Sexual Politics, US: University of Illinois Press, 2000.

Mulvey, Laura .'Visual Pleasure and Narrative Cinema', Screen, xvi(iii), (1975).

Negi, Mohita. "Rise of women's Theatre in India," Your Article Library; The Next Generation Library, accessed December 3, 2019, https:/www.yourarticlelibrary.com/essay/rise-of-womens-theatre-inindia/24346.

Oddey, Alison. Devising Theatre; A Practical and Theoretical Handbook. New York: Routledge, 1994.

Pajewski, Claudia. "The Indian Woman Using her Body to Fight for Equality", bbcnews.com, last modified, December 21, 2017, https://www.bbc.com/news/world-asia-india-42349844

Rani, Savita. "RIP”, video, accessed February 4, 2021, https:/www.youtube.com/

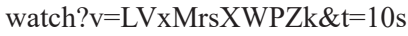

Rao, Maya Krishna. "Quality Streets”, video, accessed January 3, 2021, https://www.youtube.com/

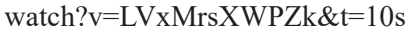

Rao, Maya Krishna. "Walk", video, last modified, February 9, 2013, https://www.youtube.com/ watch?v=msUvCWKcCVQ

Rao, video, Maya Krishna. 6:17, uploaded on February 17, 2013, https://www.youtube.com/ watch? $\mathrm{v}=\mathrm{Uv} 7 \mathrm{UdX}$ vrybU.

Singh, Anita. "Aesthetics of Indian Feminist Theatre", Rupkatha Journal on Interdisciplinary Studies of Humanities 1, no. 2 (2009).

Srikumar, Priya. "Rest in Peace Throughout Life," Deccan Chronicle, last modified 17 Fab, 2017,https://www.deccanchronicle.com/entertainment/theatre/170217/rest-in-peace-throughoutlife. html?fbclid=IwAR1newED6TCPQUyQbxjzFsbUdXTdG1ePxs4DmjHWAwaUVpP4qDGIc2_hMDY

Taneja, Mallika. "My Indian life, Part-2: A Body of Protest," interviewed by Kalki Koechlin, bbcnews, accessed 22 December, 2020, https:/www.youtube.com/watch?v=9JT1BPBZO3A

Taneja, Mallika. "Thora Dhyan se (Be Little careful)", video, 1:02, accessed 2 February 2021, https://www. youtube.com/watch? $=$ giNBlGGmxZg

Vohra, Kinnari. 'Women That Man Created', Theatre India: National School of Drama's Theatre Journal 3 (May 2001). 
